Article

\title{
Analysis of the Impact of Working Environment Factors on Employee's Health and Wellbeing; Workplace Lighting Design Evaluation and Improvement
}

\author{
Ružena Králiková, Ervin Lumnitzer, Laura Džuňová * and Anna Yehorova (C)
}

check for

updates

Citation: Králiková, R.; Lumnitzer, E.; Džuňová, L.; Yehorova, A. Analysis of the Impact of Working Environment Factors on Employee's Health and Wellbeing; Workplace Lighting Design Evaluation and Improvement. Sustainability 2021, 13, 8816. https://doi.org/10.3390/ su13168816

Academic Editor: João Carlos de Oliveira Matias

Received: 5 July 2021

Accepted: 5 August 2021

Published: 6 August 2021

Publisher's Note: MDPI stays neutral with regard to jurisdictional claims in published maps and institutional affiliations.

Copyright: (c) 2021 by the authors. Licensee MDPI, Basel, Switzerland. This article is an open access article distributed under the terms and conditions of the Creative Commons Attribution (CC BY) license (https:/ / creativecommons.org/licenses/by/ $4.0 /)$.
Department of Process and Environmental Engineering, Technical University of Kosice, 04001 Kosice, Slovakia; ruzena.kralikova@tuke.sk (R.K.); ervin.lumnitzer@tuke.sk (E.L.); anna.yehorova@tuke.sk (A.Y.)

* Correspondence: laura.dzunova@tuke.sk

\begin{abstract}
In modern society, humans spend most of their time in the indoor environment (home, work, school...). This indoor lifestyle constantly poses challenges to our physical and mental health by affecting our hormone levels and circadian rhythm. This article deals with the possible connection between human and working environment factors and the emergence of health problems in connection with work. Using statistical methods, the dependence between the six characteristics (age, length of employment, visual demand of the work task, satisfaction with lighting conditions, and shift work) and occurrence of health-related problems and discomfort (i.e., eye discomfort, headache, eye fatigue, and seasonal affective disorder symptoms) was examined. The paper also deals with the evaluation of lighting conditions in the workshop using the lighting design software DIALux evo 9.2. Using this software, two lighting variants were modeled. The first simulated variant included lighting parameters according to the currently used luminaries and the second variant contained more efficient LED luminaries.
\end{abstract}

Keywords: working environment factors; health and safety; workplace lighting; visual comfort

\section{Introduction}

From evolution, human organisms were adapted to the natural alternation of light and darkness, by the internal process that regulates the sleep-wake cycle called the circadian rhythm. However, in the last millennium with the appearance of an artificial light source and its development, the human lifestyle began to change and that led to disturbance of this circadian cycle. Humans started to lengthen their day and shortened their night. It was only a matter of time for people to address the potential negative impact of these changes associated with the use and development of artificial lighting and its interventions with the human body's natural biorhythm $[1,2]$.

Optimized lighting has a lot of positive features that are beneficial for increasing comfort and safety in the indoor environment. Additionally, the beneficial effects of good lighting extend much further than it was originally thought. In fact, over the last two decades, medical science has consistently shown that natural daylight has a positive influence on human health and well-being. Daylight regulates human physiology, behavior, and the sleep-wake cycle, by directly stimulating the internal timing mechanisms of the brain. Since humans spend most of their time in the indoor environment, the lighting in the interiors should be designed to contain as much daylight as possible, combined with added artificial lighting that can be adapted to the human needs in the absence of daylight to ensure best visibility and suitability. The modern lifestyle is characterized by a mismatch between circadian and societal (e.g., shift work, school) clocks, a condition known as social jet lag, which can have severe impacts on human health and well-being [3,4].

The modern lifestyle and social jet lag can disturb circadian clock systems and prevent correct entrainment to periodically changing environmental conditions, most importantly 
the light-dark cycle. Disruption of and misalignment between internal and external rhythms has been associated with numerous health consequences, including metabolic and cardiovascular diseases, psychiatric disorders, cancer, or even increased mortality [5].

Human physical function is influenced by light irradiation, and interest of its influence on health is high. The results of a study that examined the influences of three different light sources on neural activity in the paraventricular nucleus $(\mathrm{PVN})$ region using two different color temperatures, suggest that differences in the light source or color temperature may affect the stress response. Studies $[1,2,6,7]$ have shown that the body's hormone levels rise and fall during the day in response to the availability of natural light.

Increasing light levels make people feel energized and active but as daylight intensity diminishes, the opposite is true. Light has a profound effect on our physical and emotional health $[1,8]$. There are several studies that demonstrate the effect of lighting on the human body. Daylight synchronizes the biological clock and affects hormonal rhythms (melatonin and cortisol) and has a direct effect on brain function. Thus, we can assume that it affects an employee's work performance and productivity [9]. Optimized lighting can have many positive features that are beneficial for increasing comfort and safety in the indoor environment. Several studies [10-12] have addressed the effect of dynamic lighting on health and well-being. A study [13] in the office environment proves that people are happier when they have the ability to control and adjust the lighting in their workplace.

Several studies [2,14-16] show that the work environment is one of the important factors influencing the performance and productivity of employees, as well as the wellbeing of employees and the occurrence of occupational diseases. An industrial study [17] showed an increase in the productivity of employees as the level of lighting is increased.

Good lighting solutions that deliver the right level of light at different times of the day enhance people's sense of well-being, improving concentration, motivation, and performance. Suitable indoor lighting is a prerequisite for optimizing vision performance, visual comfort, and comfort of the working environment and the positive effects of adequate lighting can be extended even further.

\subsection{Perception of Lighting in the Workplace}

The perception of lighting depends on several aspects such as illuminance uniformity, luminance distributions, light color characteristics, and glare. There are differences between individuals in what is considered comfortable lighting. In general, appropriate workplace lighting means finding a balance between human needs and the company's resources [18]. Figure 1 provides a graphical representation of the relationship between employee satisfaction and workplace lighting [19].

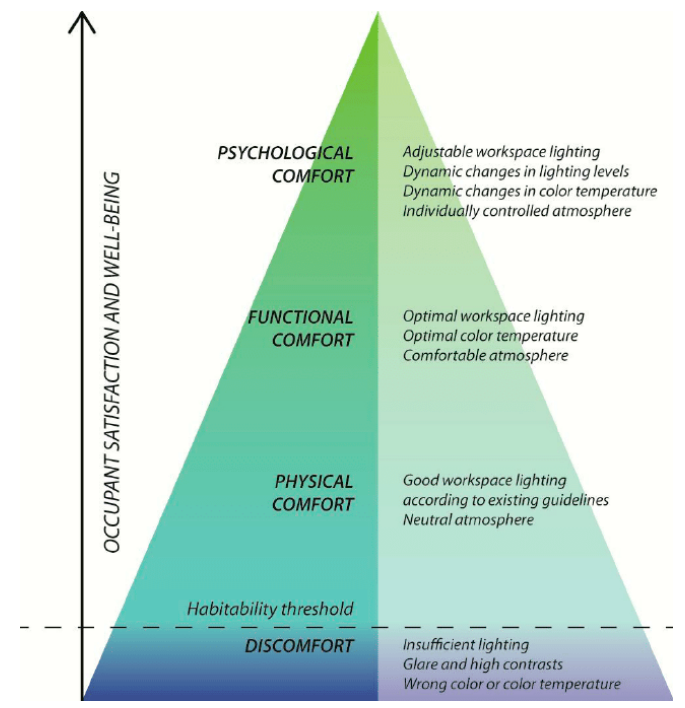

Figure 1. Environmental comfort model adapted to workplace lighting [19]. 
The influence of artificial lighting on the psychophysiological well-being of people depends on the lighting source kind, regarding its brightness, illuminance, color spectrum, and light distribution in the room [20]. The effect of artificial lighting on humans is most pronounced in indoor spaces with the absence of natural daylight.

In practice, we encounter the focus of lighting design, especially on providing the necessary lighting to perform work activities, but lighting that is sufficient to perform the work task may not necessarily be sufficient for the mental and physical well-being of the employee. There are several lighting-related factors that may cause visual discomfort [21-23]. Both insufficient lighting and too much light can lead to unsuitable lighting. As well, completely uniform lighting and too non-uniform lighting in space are both undesirable because they may cause distraction and discomfort [18].

\subsection{Psychological and Biological Effects of the Lighting}

In recent years, there has been a development in the field of research aimed at comparing the effects of natural light and artificial light on humans. Photobiology is the scientific study of the interactions of light and living organisms. The photobiology of modern science deals with the study of the effects of light on the human body. Quite a few studies have focused on the use of light to treat the seasonal affective disorder (SAD) [24-28]. Seasonal affective disorder is a type of depression which occurs when you develop symptoms of depression during the darker winter months each year. Winter blues or subsyndromal seasonal affective disorder (S-SAD) is a less severe form of the condition. One of its external symptoms is mental depression; other symptoms include sadness, lack of energy, apathy, weight gain, and inattention.

Biological effects of lighting are also called non-visual effects and are related to the human circadian photoreception. The internal symptom is a hormonal imbalance between melatonin and serotonin. Melatonin and serotonin levels are affected by light intensity. With higher light intensity its production of melatonin slows down, but at night its amount increases up to ten times more than during the day. Melatonin is involved in synchronizing the circadian rhythm, including sleep-wake timing, blood pressure regulation, and seasonal reproduction. On the contrary with higher light intensity the amount of serotonin increases and higher levels of serotonin correlate with better mood, feelings of satisfaction and lower chance at depression and anxiety. Several researchers have investigated the effect of natural light and artificial light on human's circadian rhythm and mood [28-33].

The luminous environment can be perceived in many ways e.g., as more or less agreeable, attractive, and appropriate to the function of the space. Variations of luminance and colors can strengthen attractiveness, trigger emotions, and affect employees' mood, the impact of lighting depends much on the individuals and their state of mind. Lighting should be designed to provide people with the right visual conditions that help them to perform visual tasks efficiently, safely, and comfortably [2].

\section{Materials and Methods}

An industrial plant focused on the production of components for the automotive industry was selected for the investigation of the employee's health and comfort based on selected characteristics. We decided to choose the automotive-related industrial plant due to high employment in this sector in our region in Slovakia. Production plants employ a wide range of employees regardless of age, gender, etc. Additionally, it is shift work in the indoor environment of the production hall, mostly with the artificial or combined type of lighting, which was suitable for our research. Participants were approached and selected in such a way as to ensure variability in filling in the questionnaire, but at the same time, reflect the status of employment in the company. Participants were mainly production operators, quality control operators, and maintenance workers working in a 4-shift schedule.

Using a questionnaire survey and statistical methods, we verified the interdependence between four selected characters related to the employees and their employment (charac- 
ters $\mathrm{X}_{\mathrm{i}}$ ) and four characters representing health-related problems (characters $\mathrm{Y}_{\mathrm{i}}$ ) shown in Table 1.

Table 1. Selected characters.

\begin{tabular}{cccc}
\hline & Characters $\mathbf{X}_{\mathbf{i}}$ & Characters $\mathbf{Y}_{\mathbf{i}}$ \\
\hline $\mathrm{X}_{1}$ & Age & $\mathrm{Y}_{1}$ & $\begin{array}{c}\text { Eye irritation (sore, burning, } \\
\text { tearing or itchy eyes) }\end{array}$ \\
\hline $\mathrm{X}_{2}$ & Length of employment & $\mathrm{Y}_{2}$ & Headache due to eyestrain \\
\hline $\mathrm{X}_{3}$ & $\begin{array}{c}\text { Visual demand of } \\
\text { the work }\end{array}$ & $\mathrm{Y}_{3}$ & $\begin{array}{c}\text { Eye fatigue (blurry vision, } \\
\text { red, dry, tired eyes) }\end{array}$ \\
\hline $\mathrm{X}_{4}$ & Satisfaction with lighting & $\mathrm{Y}_{4}$ & $\begin{array}{c}\text { Seasonal affective disorder (SAD) } \\
\text { symptoms (depression, lack of } \\
\text { energy, sleep problems) }\end{array}$ \\
\hline $\mathrm{X}_{5}$ & Night shift & & \\
\hline $\mathrm{X}_{6}$ & Day shift & \\
\hline
\end{tabular}

The survey was conducted on 100 employees of a selected unnamed industrial plant, of which 58 were men and 42 women. The employees work in 4-shift schedule working $12 \mathrm{~h}$ (day shift-night shift-2x free day). Workers of each shift were asked to complete a questionnaire in the middle of their shift work, stating their age, length of employment, category of work in terms of visual demand, and work shift as well as answering five questions related to satisfaction with lighting conditions and experiencing of vision-related health problems. The questionnaire was filled in by 50 employees on a day shift and 50 employees on a night shift. The distribution of employees by age, length of employment, and how their performed work is visually demanding is shown in Table 2. The questions were formulated as follows:

- When performing your work, do you feel eye irritation (e.g., sore, burning, tearing, or itchy eyes)?

- Do you have headaches as a result of work-related excessive eyestrain?

- When performing your work, do you feel eye fatigue (blurry vision, red, dry, or tired eyes)?

- Do you experience depression, lack of energy, or sleep problems in connection with the performance of your work?

- What is your level of satisfaction with lighting conditions in the workplace, when performing your work?

Table 2. Distribution of responders by age, length of employment, and labor intensity.

\begin{tabular}{ccc}
\hline \multicolumn{2}{c}{ Distribution of Employees by } & Number of Respondents \\
\hline & $<30$ & 44 \\
Age group & $30-40$ & 23 \\
& $40-50$ & 19 \\
& $>50$ & 14 \\
\hline & $<5$ years & 50 \\
Length of & $5-10$ years & 21 \\
employment & $10-15$ years & 12 \\
& $>15$ years & 17 \\
\hline & Very accurate & 14 \\
Visual demand & Accurate & 35 \\
of the work & Moderately accurate & 39 \\
& Rough & 12 \\
\hline
\end{tabular}


The response scale was formulated as follows: disagree, rather disagree, rather agree, agree. The frequency of answers to the above questions is given in Table 3 .

Table 3. Frequency of answers from the questionnaire survey.

\begin{tabular}{ccccc}
\hline & Eye Irritation & Headache & Eye Fatigue & SAD Symptoms \\
\hline Disagree & 21 & 20 & 21 & 23 \\
Rather disagree & 25 & 28 & 19 & 44 \\
Rather agree & 32 & 29 & 36 & 25 \\
Agree & 22 & 23 & 24 & 8 \\
\hline
\end{tabular}

We examined whether the characters $X_{i}$ and $Y_{i}$ are statistically significant, as well as the degree of their dependence. In most cases, a moderate dependence was found between selected indicators. Contingency tables were used to visualize the relationship between the two statistical features. The rows of the PivotTable correspond to the possible values of the first character, the columns to the possible values of the second character. Using a contingency chart, an overview of this data was subsequently created. A nonparametric Pearson's Chi-square test was used for testing.

The procedure was in the following steps:

1. Compilation of contingency tables and graphs showing the research groups and their views.

2. Compilation of the null hypothesis $\mathrm{H}_{0}$ and the alternative hypothesis $\mathrm{H}_{\mathrm{n}}$.

3. Determinations of the Chi-square limit value at the selected level of significance.

4. Calculation of the test criterion, Chi-square according to the relation:

$$
\chi^{2}=\sum \frac{(\mathrm{O}-\mathrm{E})^{2}}{\mathrm{E}}
$$

Comparison of the calculated Chi-square value with the tabular Chi-square value at the selected significance level. Where: $\mathrm{O}$-observed frequencies; $\mathrm{E}$-expected frequencies.

5. Evaluation: If the calculated value is lower than the table value, we do not reject $\mathrm{H}_{0}$. If our Chi-square value is higher than the corresponding table, we reject $\mathrm{H}_{0}$ and accept the alternative hypothesis $\mathrm{H}_{\mathrm{n}}$.

\section{Results}

The evaluation of individual $X_{i}$ and $Y_{i}$ characters (Table 1) obtained from the questionnaires was processed in contingency tables and graphs. Based on the data from the questionnaire survey, a statistical evaluation of the dependence and the degree of significance of the monitored indicators was performed. The hypotheses $\mathrm{H}_{\mathrm{n}}$ were investigated. The established hypotheses were tested by Pearson's Chi-square test $(\alpha=0,05)$ of independence and the degree of dependence was determined by the Cramer's coefficient, using the scale given in Table 4 .

Table 4. Association coefficient interpretation.

\begin{tabular}{cc}
\hline \multicolumn{2}{c}{ Cramer's V Interpretation } \\
\hline$<0.1$ & negligible dependence \\
$0.1-0.3$ & weak dependence \\
$0.3-0.5$ & moderate dependence \\
$>0.5$ & strong dependence \\
\hline
\end{tabular}

With the null hypothesis $\mathrm{H}_{0}$, it was assumed that the observed characters $X_{i}$ and $Y_{i}$ are independent. The tested hypotheses $H_{n}$ assume that the observed characters $X_{i}$ and $Y_{i}$ are dependent. 
A graphical representation of the occurrence of $Y_{i}$ according to individual character $X_{1}$ is shown in Figure 2. The tested $H_{1}$ hypothesis is: characters $Y_{i}$ and the age of employees $\left(X_{1}\right)$ are dependent. Table 5 shows the results of the Chi-Square test of independence for $\mathrm{H}_{1}$ hypothesis.

25

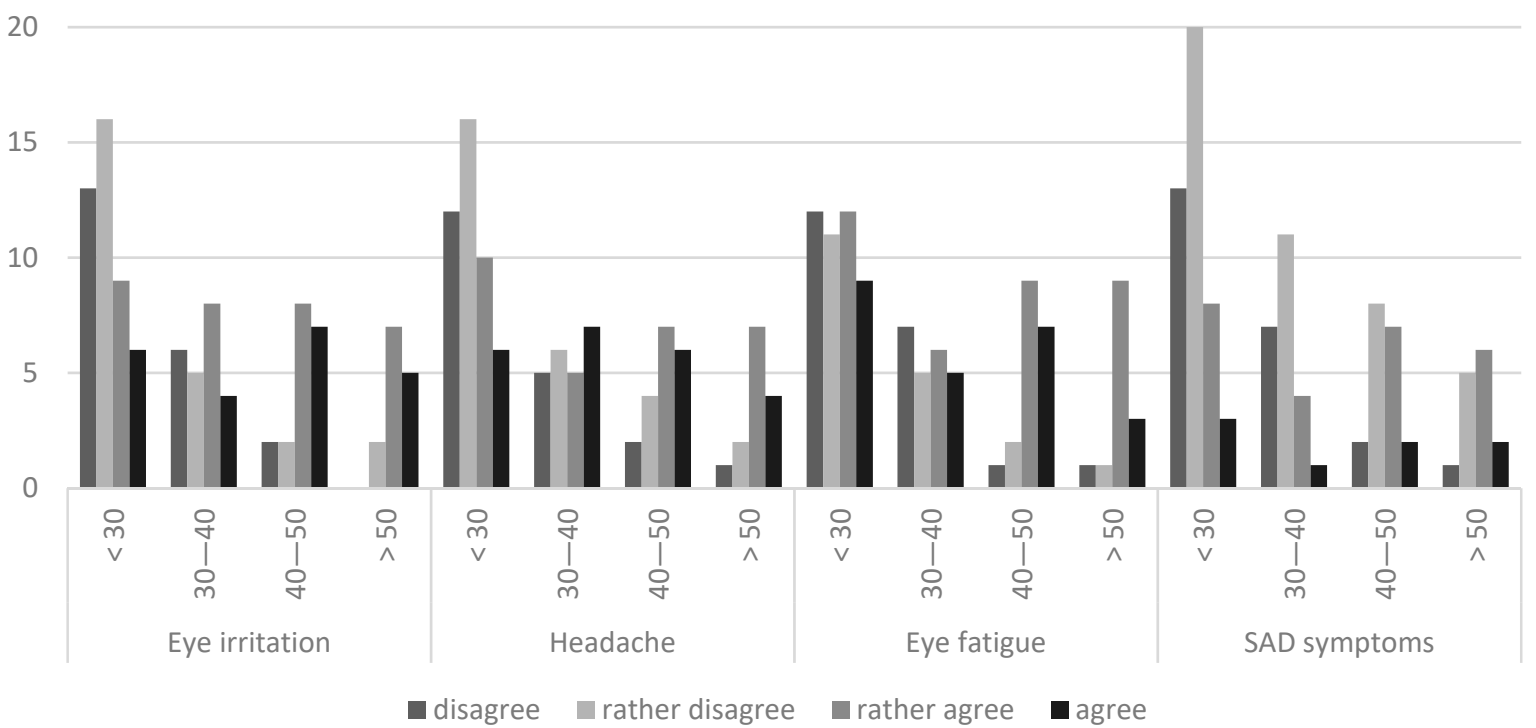

Figure 2. Occurrence of vision problems by age group.

Table 5. Evaluation of the dependence of vision problems on the age of employees.

\begin{tabular}{|c|c|c|c|c|}
\hline \multicolumn{5}{|c|}{ Character $\mathrm{X}_{1}-$ Age } \\
\hline Characters $\mathrm{Y}_{\mathrm{i}}$ & $\mathrm{Y}_{1}$-Eye Irritation & $\begin{array}{c}\mathrm{Y}_{2}-\text { Headache Due } \\
\text { to Eyestrain }\end{array}$ & $\mathrm{Y}_{3}$-Eye Fatigue & $\mathrm{Y}_{4}$-SAD Symptoms \\
\hline Test criterion $\left(\chi^{2}\right)$ & 17,485 & 10,328 & 12,684 & 80,610 \\
\hline$P$ value & 0.0006 & 0.016 & 0.0054 & 0.0448 \\
\hline Decision & $\mathrm{H}_{0}$ is rejected & $\mathrm{H}_{0}$ is rejected & $\mathrm{H}_{0}$ is rejected & $\mathrm{H}_{0}$ is rejected \\
\hline Result & $\begin{array}{c}\text { There is dependence } \\
\text { between characters } \\
\mathrm{X}_{1} \text { and } \mathrm{Y}_{1}\end{array}$ & $\begin{array}{c}\text { There is dependence } \\
\text { between characters } \\
X_{1} \text { and } Y_{2}\end{array}$ & $\begin{array}{c}\text { There is dependence } \\
\text { between characters } \\
X_{1} \text { and } Y_{3}\end{array}$ & $\begin{array}{c}\text { There is dependence } \\
\text { between characters } \\
X_{1} \text { and } Y_{4}\end{array}$ \\
\hline Cramer's coefficient & $\begin{array}{c}0.4182-\text { moderate } \\
\text { dependence }\end{array}$ & $\begin{array}{l}\text { 0.3214-moderate } \\
\text { dependence }\end{array}$ & $\begin{array}{l}0.3561 \text {-moderate } \\
\text { dependence }\end{array}$ & $\begin{array}{l}0.2839 \text {-weak } \\
\text { dependence }\end{array}$ \\
\hline
\end{tabular}

A graphical representation of the occurrence of $Y_{i}$ according to individual character $\mathrm{X}_{2}$ is shown in Figure 3. The tested $\mathrm{H}_{2}$ hypothesis is: characters $\mathrm{Y}_{\mathrm{i}}$ and the length of employment $\left(X_{2}\right)$ are dependent. Table 6 shows the results of the Chi-Square test of independence for $\mathrm{H}_{2}$ hypothesis.

A graphical representation of the occurrence of $Y_{i}$ according to individual character $\left(X_{3}\right)$ is shown in Figure 4. The tested $H_{3}$ hypothesis is: characters $Y_{i}$ and the visual demand of the work $\left(X_{3}\right)$ are dependent. Table 7 shows the results of the Chi-Square test of independence for $\mathrm{H}_{3}$ hypothesis.

A graphical representation of the occurrence of $Y_{i}$ according to individual character $\left(\mathrm{X}_{4}\right)$ is shown in Figure 5. The tested $\mathrm{H}_{4}$ hypothesis is: characters $\mathrm{Y}_{\mathrm{i}}$ and the workers' satisfaction with lighting conditions $\left(\mathrm{X}_{4}\right)$ are dependent. Table 8 shows the results of the Chi-Square test of independence for $\mathrm{H}_{4}$ hypothesis. 


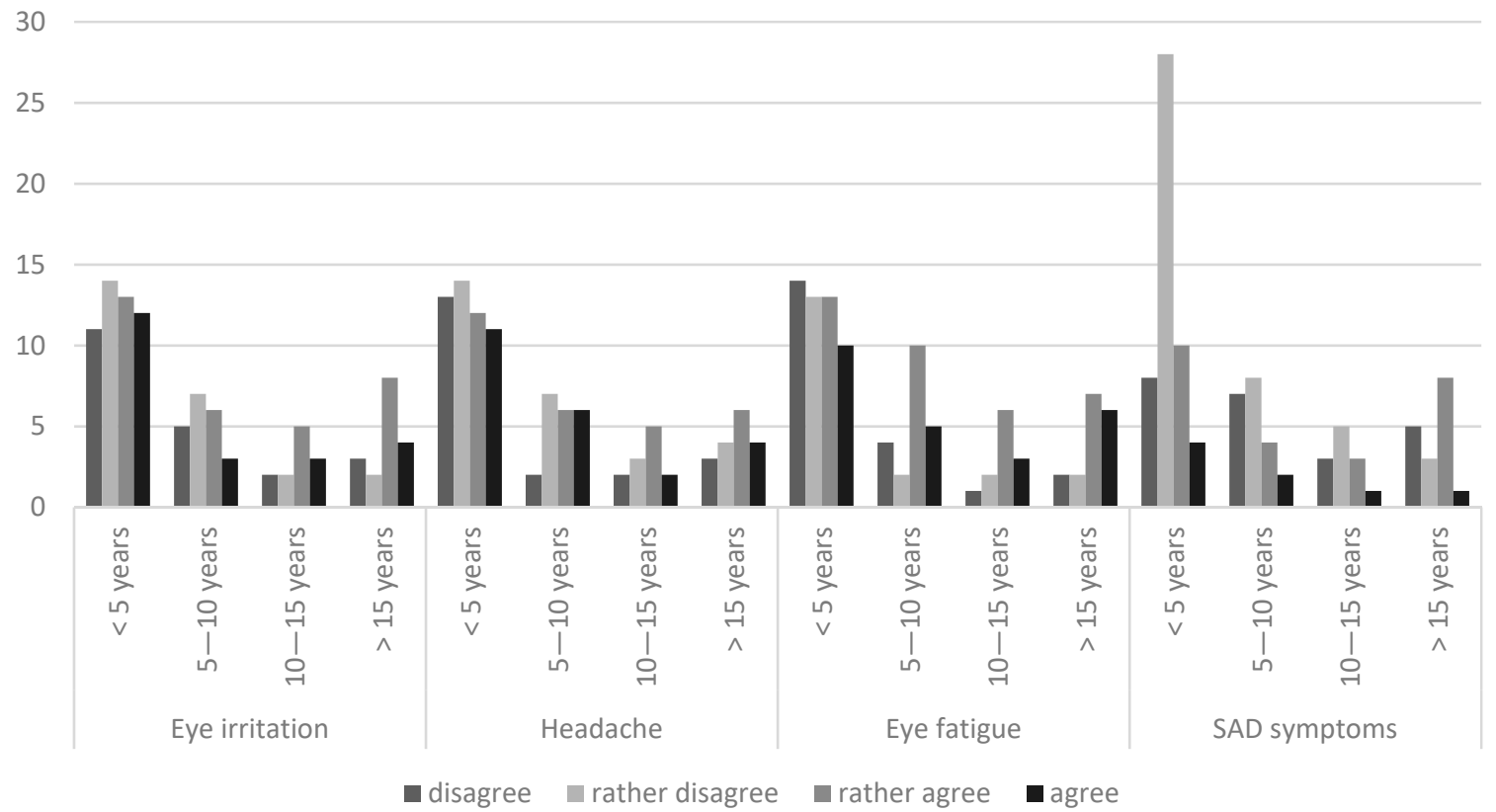

Figure 3. Occurrence of vision problems according to length of employment.

Table 6. Evaluation of the dependence of vision problems on the length of employment.

\begin{tabular}{|c|c|c|c|c|}
\hline \multicolumn{5}{|c|}{ Character $\mathrm{X}_{2}$-Length of Employment } \\
\hline Characters $Y_{i}$ & $\mathrm{Y}_{1}$-Eye irritation & $\begin{array}{l}Y_{2}-\text { Headache due to } \\
\text { eyestrain }\end{array}$ & $\mathrm{Y}_{3}$-Eye fatigue & $\mathrm{Y}_{4}$-SAD symptoms \\
\hline Test criterion $\left(\chi^{2}\right)$ & 4033 & $\begin{array}{l}\text { eyestrain } \\
1457\end{array}$ & 8275 & 38,130 \\
\hline$P$ value & 0.2582 & 0.693 & 0.0407 & 0.2828 \\
\hline Decision & $\mathrm{H}_{0}$ is not rejected & $\mathrm{H}_{0}$ is not rejected & $\mathrm{H}_{0}$ is rejected & $\mathrm{H}_{0}$ is not rejected \\
\hline & There is no dependence & There is no dependence & There is dependence & There is no dependence \\
\hline Result & between characters & between characters & between characters & between characters \\
\hline Cramer's coefficient & & & $\begin{array}{l}X_{2} \text { and } Y_{3} \\
0.2877-\text { weak dependence }\end{array}$ & \\
\hline
\end{tabular}

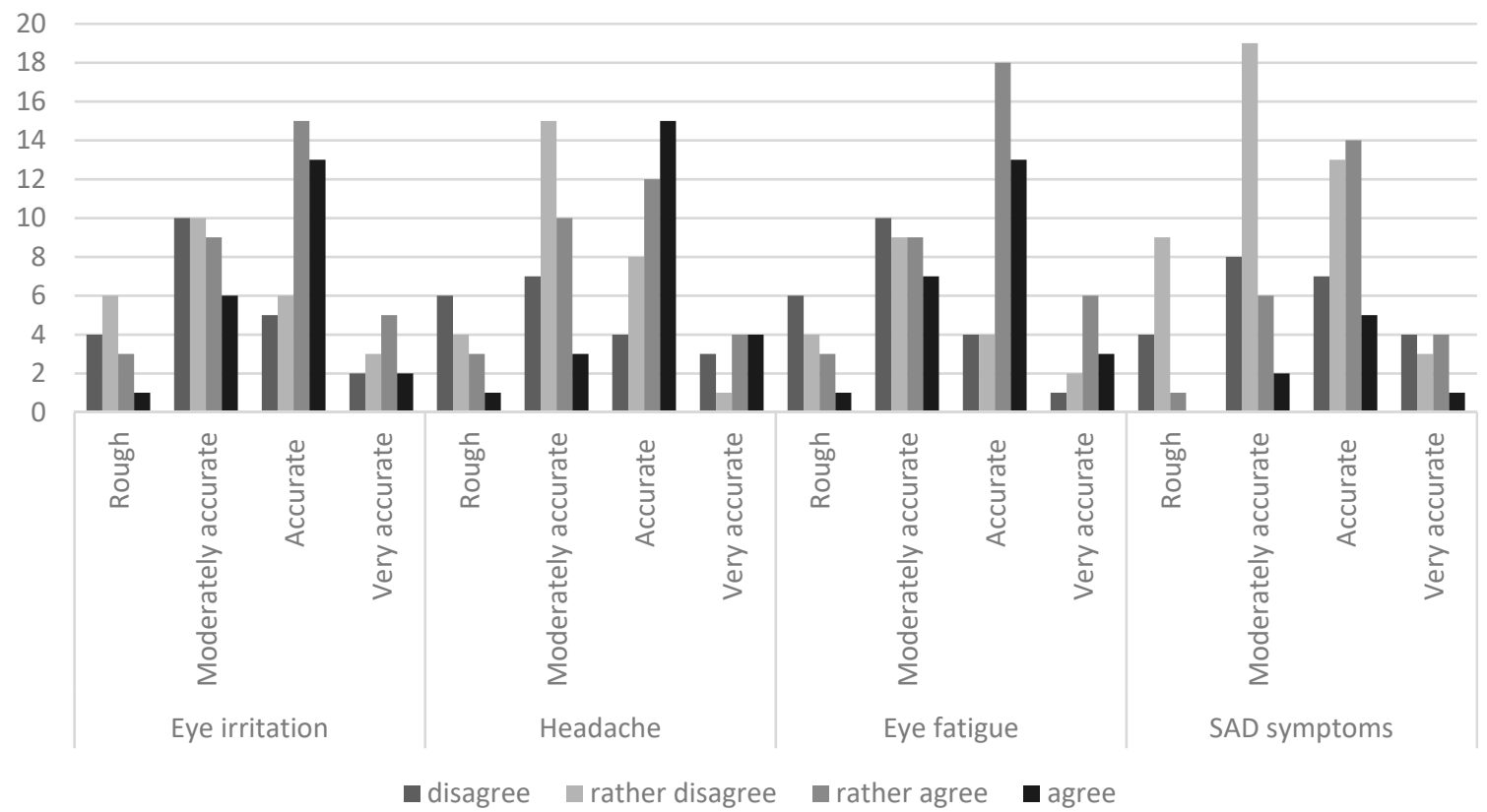

Figure 4. Occurrence of vision problems according to visual demand of work task. 
Table 7. Evaluation of the dependence of vision problems on the visual demand of the work.

\begin{tabular}{|c|c|c|c|c|}
\hline \multicolumn{5}{|c|}{ Character $\mathrm{X}_{3}-$ Visual Demand of the Work Task } \\
\hline Characters $Y_{i}$ & $\mathrm{Y}_{1}$-Eye irritation & $\begin{array}{c}\mathrm{Y}_{2}-\text { Headache due } \\
\text { to eyestrain }\end{array}$ & $\mathrm{Y}_{3}$-Eye fatigue & $\mathrm{Y}_{4}$-SAD symptoms \\
\hline Test criterion $\left(\chi^{2}\right)$ & 104,580 & 118,500 & 160,370 & 106,330 \\
\hline$P$ value & 0.0151 & 0.0079 & 0.0011 & 0.0139 \\
\hline Decision & $\mathrm{H}_{0}$ is rejected & $\mathrm{H}_{0}$ is rejected & $\mathrm{H}_{0}$ is rejected & $\mathrm{H}_{0}$ is rejected \\
\hline Result & $\begin{array}{c}\text { There is dependence } \\
\text { between characters } \\
X_{3} \text { and } Y_{1}\end{array}$ & $\begin{array}{c}\text { There is dependence } \\
\text { between characters } \\
X_{3} \text { and } Y_{2}\end{array}$ & $\begin{array}{c}\text { There is dependence } \\
\text { between characters } \\
X_{3} \text { and } Y_{3}\end{array}$ & $\begin{array}{c}\text { There is dependence } \\
\text { between characters } \\
X_{3} \text { and } Y_{4}\end{array}$ \\
\hline Cramer's coefficient & $\begin{array}{l}0.3234 \text {-moderate } \\
\text { dependence }\end{array}$ & $\begin{array}{l}0.3442 \text {-moderate } \\
\text { dependence }\end{array}$ & $\begin{array}{l}0.4005 \text {-moderate } \\
\text { dependence }\end{array}$ & $\begin{array}{l}0.3261 \text { - moderate } \\
\text { dependence }\end{array}$ \\
\hline
\end{tabular}

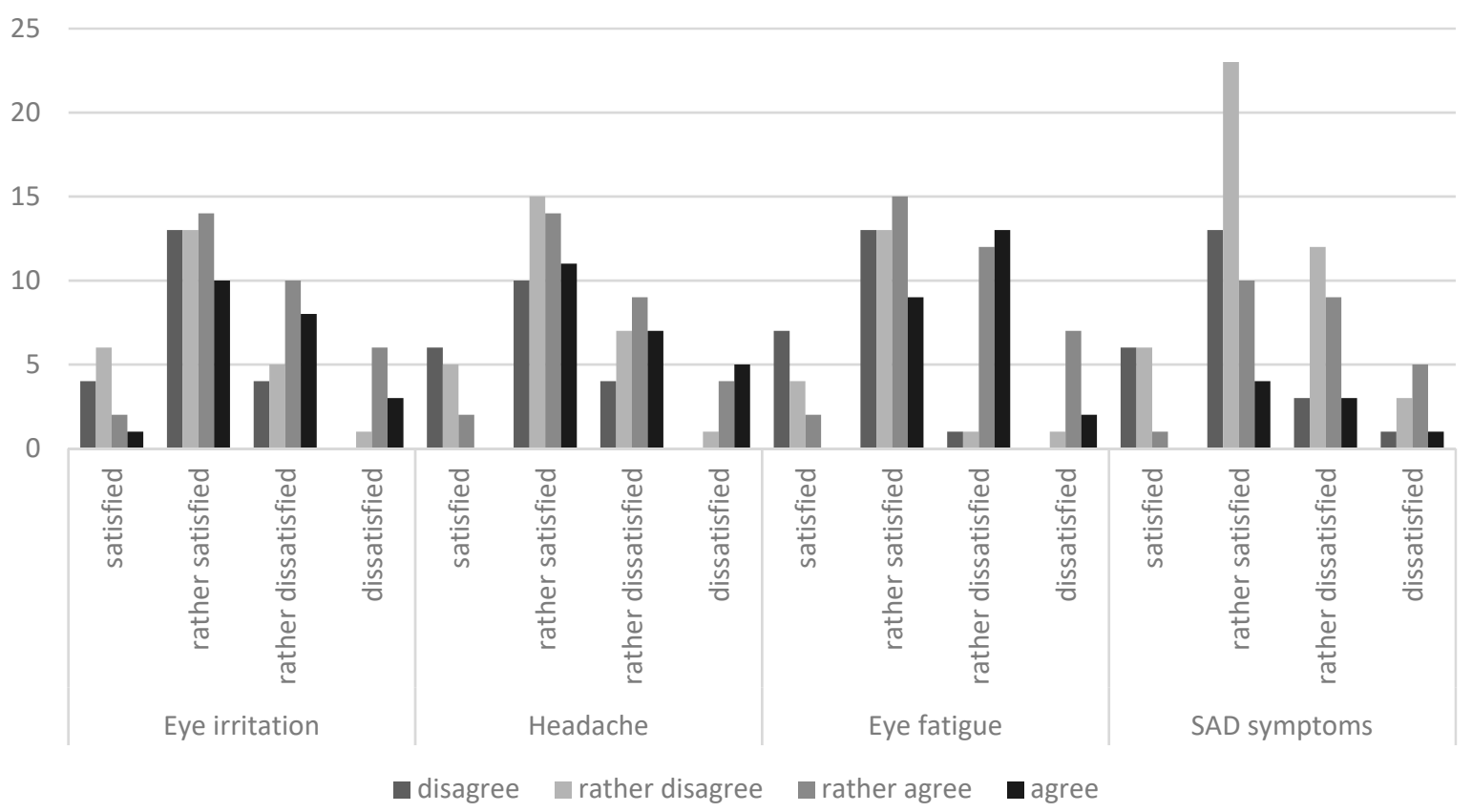

Figure 5. Occurrence of vision problems according to satisfaction with the lighting conditions.

Table 8. Evaluation of the dependence of vision problems on the visual demand of the work.

\begin{tabular}{|c|c|c|c|c|}
\hline \multicolumn{5}{|c|}{ Character $\mathrm{X}_{4}$-Satisfaction with Lighting Conditions } \\
\hline Characters $Y_{i}$ & $\mathrm{Y}_{1}$-Eye irritation & $\begin{array}{c}\mathrm{Y}_{2}-\text { Headache due to } \\
\text { eyestrain }\end{array}$ & $\mathrm{Y}_{3}$-Eye fatigue & $\mathrm{Y}_{4}$-SAD symptoms \\
\hline Test criterion $\left(\chi^{2}\right)$ & 126,950 & 134,220 & 294,850 & 92,320 \\
\hline$P$ value & 0.0053 & 0.0038 & 0.0000 & 0.0264 \\
\hline Decision & $\mathrm{H}_{0}$ is rejected & $\mathrm{H}_{0}$ is rejected & $\mathrm{H}_{0}$ is rejected & $\mathrm{H}_{0}$ is rejected \\
\hline Result & $\begin{array}{c}\text { There is dependence } \\
\text { between characters } \\
X_{4} \text { and } Y_{1}\end{array}$ & $\begin{array}{c}\text { There is dependence } \\
\text { between characters } \\
X_{4} \text { and } Y_{2}\end{array}$ & $\begin{array}{c}\text { There is dependence } \\
\text { between characters } \\
X_{4} \text { and } Y_{3}\end{array}$ & $\begin{array}{c}\text { There is dependence } \\
\text { between characters } \\
\mathrm{X}_{4} \text { and } \mathrm{Y}_{4}\end{array}$ \\
\hline Cramer's coefficient & $\begin{array}{l}0.3563 \text { - moderate } \\
\text { dependence }\end{array}$ & $\begin{array}{l}0.3664 \text {-moderate } \\
\text { dependence }\end{array}$ & $\begin{array}{l}0.5430 \text { —strong } \\
\text { dependence }\end{array}$ & $\begin{array}{l}0.3038 \text { - moderate } \\
\text { dependence }\end{array}$ \\
\hline
\end{tabular}

Based on the results of the questionnaire survey and statistical tests, we came to the following statements. The summary of individual dependencies is shown in Table 9:

- There is a moderate relationship between the age of the employee and the occurrence of health problems.

- There is no provable relationship between length of employment and the occurrence of health problems. 
- There is a moderate relationship between visual demand of the work task and occurrence of health problems.

- There is a moderate relationship between satisfaction with lighting conditions and occurrence of health problems.

Table 9. Results of dependence between individual characteristics.

\begin{tabular}{ccccc}
\hline & Age & $\begin{array}{c}\text { Length of } \\
\text { Employment }\end{array}$ & $\begin{array}{c}\text { Visual Demand of } \\
\text { Work Task }\end{array}$ & $\begin{array}{c}\text { Satisfaction with } \\
\text { Lighting Conditions }\end{array}$ \\
\hline $\begin{array}{c}\text { Eye irritation } \\
\text { Headache due to } \\
\text { eyestrain }\end{array}$ & moderate dependence & unproved dependence & moderate dependence & moderate dependence \\
$\begin{array}{c}\text { Eye fatigue } \\
\text { SAD symptoms }\end{array}$ & $\begin{array}{c}\text { moderate dependence } \\
\text { weak dependence }\end{array}$ & $\begin{array}{c}\text { unproved dependence } \\
\text { weak dependence }\end{array}$ & moderate dependence & Moderatedependence \\
moderate dependence & Strongdependence \\
moderate dependence
\end{tabular}

The employees also stated in the questionnaire the type of their shift. The responses in the survey (Figure 6) show that the night-shift workers were more in agreement with the occurrence of health problems, which may be related to the disruption of circadian rhythm by artificial lighting and irregular sleep-wake rhythm due to shift work, especially by night shifts.

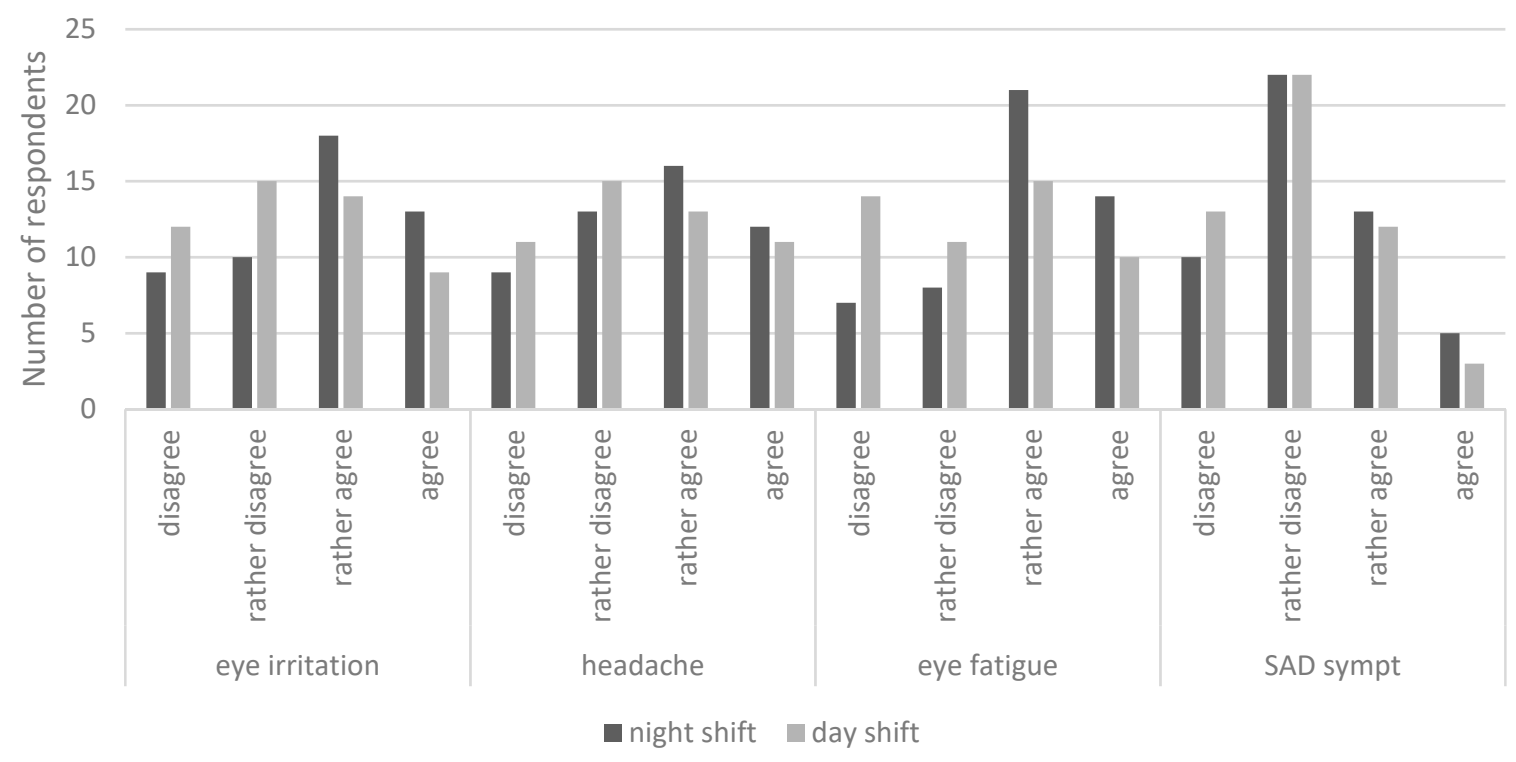

Figure 6. Occurrence of vision problems according to satisfaction with the lighting conditions.

The results of the questionnaire survey are based on the subjective opinions and feelings of employees; therefore, further research in this area is needed to objectively confirm the results of the hypotheses. However, the results of the survey point to the importance of suitable working environment as well as lighting conditions. To improve lighting in the workplace, various tools can be used, such as regular maintenance and regular control audits to find deficiencies and suggest improvements. The negative effects of poor lighting on employees can also be mitigated by raising employee's awareness of the negative effect of inadequate lighting on their health, work performance, comfort, and safety as well as to remind employees of the importance of regular eye examinations.

\section{Assessment of Lighting Conditions in the Workshop}

As the relationship between dissatisfaction with lighting conditions in the workplace and the occurrence of eye fatigue, eye irritation, headache, and SAD symptoms was demonstrated, we decided to evaluate the current lighting conditions in one of the workshops 
of the industrial plant to improve the lighting design and increase employee satisfaction with the lighting conditions. The evaluation was performed by measuring selected light parameters and by using the software DIALux evo 9.2. A new, more efficient lighting design has also been proposed to improve the lighting conditions in the workshop.

\subsection{Measurement of the Lighting Parameters}

The subject of the research was a locksmith's workshop measuring $6 \times 8 \times 2.8 \mathrm{~m}$. The workshop equipment includes a lathe, milling machine, stand drill, vertical machining center, welding table, heavy-duty table, workbench, shelf cabinet, and drawer.

The subject of the measurement was the determination of the intensity of artificial lighting in the place of the visual task and in the place of its immediate surroundings and the subsequent calculation of the uniformity of artificial lighting in the place of the visual task and in the place of its immediate surroundings. In the locksmith's workshop, the workspace is intended for the long-term stay of employees, characterized as a space with artificial lighting, and the work activity performed is in two shifts.

When measuring the intensity of lighting, the measuring points at the workplaces were chosen to represent the places of residence and movement of workers during the performance of work activities. The measurement was performed at night in the presence of employees. The measured values were not affected by daylight or other external lighting sources. The total illumination intensity was measured at a height of the horizontal reference plane of $0.85 \mathrm{~m}$. Regarding the used measurement method, the measuring instrument and the measurement conditions, the value of the expanded standard measurement uncertainty $\mathrm{U}=13.34 \%$ was calculated.

The lowest permissible values of the total maintained light intensity $\left(E_{m}\right)$ of the interior of the workplace, or its functionally defined part of the total lighting, for the employee's long-term stay in the premises are [34]:

- with sufficient daylight $\mathrm{E}_{\mathrm{m}}=200[1 \mathrm{x}]$,

- with combined lighting $\mathrm{E}_{\mathrm{m}}=500$ [lx],

- without daylight if compensatory measures are demonstrably provided, $\mathrm{E}_{\mathrm{m}}=500$ [lx],

- without daylight in other cases $\mathrm{E}_{\mathrm{m}}=1500$ [lx].

Lighting of visual task areas in the interior must meet the minimum requirements specified in the relevant legislation [34]. The average light intensity must not fall below the given values, regardless of the age and condition of the lighting system.

The measured values of the light intensity at the place of the visual task and at the place of the immediate surroundings at the locksmith workshop are given in Table 10. The following tables (Tables 11 and 12) show the calculated average values of the light intensity at the place of the visual task and at the place of the immediate surroundings, compared with the required values.

The calculated average values, extended by the measurement uncertainty, show that the lighting values at some of the measuring points do not meet the requirements of the legislation; therefore, it would be appropriate to improve the lighting design.

\subsection{Creation of the Workshop Computer Model in the DIALux Evo 9.2}

When it comes to lighting design, the use of various simulation tools is essential. The current normative requirements for lighting engineering practically exclude the manual method of calculation, because the volume of calculation operations is large, and the calculation is generally quite demanding. In addition to calculations, simulation programs also enable the creation of visualization models and their realistic display. In this part of the article, the locksmith workshop model was created and assessed in the popular lighting design software DIALux evo 9.2 [35].

The first variant represents a model of the workshop created according to the real current state of the lighting conditions using nine pieces of ES-SYSTEM CO2 154 luminaire with T5 fluorescent tube: luminous flux $3954 \mathrm{~lm}$ and connected load $60 \mathrm{~W}$. 
Table 10. Measured values of light intensity at the place of visual task and at the place of immediate surroundings.

\begin{tabular}{|c|c|c|c|c|c|c|c|c|c|c|c|c|}
\hline \multicolumn{13}{|c|}{ Measured Values (lx) } \\
\hline \multirow{2}{*}{ Workplace } & \multirow{2}{*}{$\begin{array}{l}\text { Measuring } \\
\text { Point }\end{array}$} & \multirow{2}{*}{$\begin{array}{l}\text { Measurement } \\
\text { Number }\end{array}$} & \multicolumn{5}{|c|}{ Place of Visual Task } & \multicolumn{5}{|c|}{ Place of Immediate Surroundings } \\
\hline & & & 1 & 2 & 3 & 4 & 5 & 1 & 2 & 3 & 4 & 5 \\
\hline \multirow{3}{*}{ lathe } & \multirow{3}{*}{ M1 } & 1 & 401 & 402 & 395 & 401 & 397 & 366 & 365 & 370 & 365 & 368 \\
\hline & & 2 & 430 & 431 & 435 & 431 & 428 & 356 & 357 & 351 & 350 & 357 \\
\hline & & 3 & 352 & 354 & 360 & 355 & 352 & 345 & 348 & 343 & 345 & 349 \\
\hline \multirow{3}{*}{ milling machine } & \multirow{3}{*}{ M2 } & 1 & 555 & 557 & 549 & 554 & 556 & 509 & 493 & 491 & 504 & 502 \\
\hline & & 2 & 500 & 507 & 502 & 501 & 505 & 616 & 615 & 618 & 613 & 611 \\
\hline & & 3 & 461 & 467 & 462 & 469 & 465 & 580 & 585 & 586 & 584 & 581 \\
\hline \multirow{3}{*}{ stand drill } & \multirow{3}{*}{ M3 } & 1 & 508 & 505 & 503 & 501 & 509 & 556 & 559 & 551 & 554 & 553 \\
\hline & & 2 & 490 & 493 & 498 & 488 & 494 & 450 & 451 & 453 & 459 & 452 \\
\hline & & 3 & 459 & 454 & 451 & 455 & 456 & 391 & 407 & 401 & 409 & 411 \\
\hline \multirow{3}{*}{$\begin{array}{c}\text { heavy } \\
\text { duty table }\end{array}$} & \multirow{3}{*}{ M4 } & 1 & 496 & 495 & 489 & 494 & 491 & 422 & 435 & 438 & 431 & 429 \\
\hline & & 2 & 537 & 532 & 531 & 535 & 429 & 464 & 459 & 461 & 458 & 460 \\
\hline & & 3 & 449 & 445 & 451 & 451 & 448 & 390 & 392 & 385 & 394 & 988 \\
\hline \multirow{3}{*}{$\begin{array}{l}\text { welding } \\
\text { table }\end{array}$} & \multirow{3}{*}{ M5 } & 1 & 498 & 497 & 501 & 500 & 495 & 435 & 432 & 445 & 448 & 439 \\
\hline & & $\begin{array}{l}1 \\
2\end{array}$ & $\begin{array}{l}490 \\
542\end{array}$ & 538 & 540 & 536 & 541 & $\begin{array}{l}450 \\
400\end{array}$ & $\begin{array}{l}432 \\
405\end{array}$ & $\begin{array}{l}445 \\
409\end{array}$ & $\begin{array}{l}440 \\
411\end{array}$ & $\begin{array}{l}409 \\
404\end{array}$ \\
\hline & & 3 & 454 & 456 & 449 & 453 & 452 & 473 & 489 & 485 & 496 & 485 \\
\hline \multirow{3}{*}{ workbench } & \multirow{3}{*}{ M6 } & 1 & 407 & 410 & 413 & 414 & 408 & 431 & 438 & 442 & 437 & 441 \\
\hline & & 2 & 431 & 436 & 437 & 434 & 431 & 455 & 459 & 460 & 458 & 462 \\
\hline & & 3 & 364 & 365 & 370 & 369 & 373 & 348 & 342 & 349 & 451 & 348 \\
\hline
\end{tabular}

Table 11. Comparison of measured values at the location of the visual task with the required values.

\begin{tabular}{|c|c|c|c|c|c|c|c|}
\hline \multirow{3}{*}{ Workplace } & \multirow{2}{*}{$\begin{array}{l}\text { Measuring } \\
\text { Point }\end{array}$} & \multirow{2}{*}{$\begin{array}{l}\text { Average Light } \\
\text { Intensity }\end{array}$} & \multirow{2}{*}{$\begin{array}{l}\text { Measurement } \\
\text { Uncertainty }\end{array}$} & \multirow{2}{*}{ Result } & \multirow{2}{*}{$\begin{array}{l}\text { Required Light } \\
\text { Intensity }\end{array}$} & \multicolumn{2}{|c|}{ Lighting Uniformity } \\
\hline & & & & & & Measured & Required \\
\hline & $\mathbf{M}$ & $E_{m}(1 x)$ & U (\%) & $\overline{\mathbf{E}} \pm \mathbf{U}(\mathbf{l x})$ & $E_{m}(1 x)$ & $\mathbf{R}$ & $\mathbf{R}$ \\
\hline lathe & M1 & 394.93 & 13.34 & $394.93 \pm 52.68$ & $\geq 500$ & 0.89 & $\geq 0.7$ \\
\hline milling machine & M2 & 507.33 & 13.34 & $507.33 \pm 67.68$ & $\geq 500$ & 0.91 & $\geq 0.7$ \\
\hline stand drill & M3 & 484.27 & 13.34 & $484.27 \pm 64.60$ & $\geq 500$ & 0.93 & $\geq 0.7$ \\
\hline heavy-duty table & M4 & 484.87 & 13.34 & $484.87 \pm 64.68$ & $\geq 500$ & 0.88 & $\geq 0.7$ \\
\hline welding table & M5 & 496.80 & 13.34 & $496.80 \pm 66.27$ & $\geq 500$ & 0.90 & $\geq 0.7$ \\
\hline workbench & M6 & 404.13 & 13.34 & $404.13 \pm 53.91$ & $\geq 500$ & 0.90 & $\geq 0.7$ \\
\hline
\end{tabular}

Table 12. Comparison of measured values in the immediate vicinity with the required values.

\begin{tabular}{|c|c|c|c|c|c|c|c|}
\hline \multirow{3}{*}{ Workplace } & \multirow{2}{*}{$\begin{array}{c}\text { Measuring } \\
\text { Point }\end{array}$} & \multirow{2}{*}{$\begin{array}{l}\text { Average Light } \\
\text { Intensity }\end{array}$} & \multirow{2}{*}{$\begin{array}{l}\text { Measurement } \\
\text { Uncertainty }\end{array}$} & \multirow{2}{*}{ Result } & \multirow{2}{*}{$\begin{array}{l}\text { Required Light } \\
\text { Intensity }\end{array}$} & \multicolumn{2}{|c|}{ Lighting Uniformity } \\
\hline & & & & & & Measured & Required \\
\hline & $\mathbf{M}$ & $E_{m}(1 x)$ & U (\%) & $\overline{\mathbf{E}} \pm \mathbf{U}(\mathbf{l x})$ & $E_{m}(1 x)$ & $\mathbf{R}$ & $\mathbf{R}$ \\
\hline lathe & M1 & 403.00 & 13.34 & $403.00 \pm 53.76$ & 300 & 0.83 & $\geq 0.5$ \\
\hline milling machine & M2 & 550.20 & 13.34 & $550.20 \pm 73.40$ & 300 & 0.82 & $\geq 0.5$ \\
\hline stand drill & M3 & 491.73 & 13.34 & $491.73 \pm 65.60$ & 300 & 0.82 & $\geq 0.5$ \\
\hline heavy-duty table & M4 & 456.13 & 13.34 & $456.13 \pm 60.85$ & 300 & 0.84 & $\geq 0.5$ \\
\hline welding table & M5 & 490.60 & 13.34 & $490.60 \pm 65.45$ & 300 & 0.86 & $\geq 0.5$ \\
\hline workbench & M6 & 404.67 & 13.34 & $404.67 \pm 53.98$ & 300 & 0.80 & $\geq 0.5$ \\
\hline
\end{tabular}

The second variant represents a new proposed lighting design model using nine pieces of LED luminaries, ES-SYSTEM COSMO APEX 1060 with luminous flux $6300 \mathrm{~lm}$ and connected load $41 \mathrm{~W}$. The new lighting model is designed to improve current lighting conditions, so the legislative requirements are met and at the same time energy costs are reduced. The second variant is focused on creating modern energy-saving lighting which would meet the requirements for visual comfort of employees as a basic condition for quality and safe performance of work in given work environment. Figure 7 shows a computer model of a locksmith workshop with marked measuring points, which has been designed to reflect the actual appearance of the workshop.

The results of the lighting calculations and subsequent simulations of both variants are shown in the following figures (Figures 8 and 9).

Table 13 compares the values of the average, minimum, and maximum values of light intensity and light uniformity obtained using the DIALux software. Based on these results it is clear that the proposed second variant of lighting model, with LED luminaries, unlike the current state model, meets the requirements of the legislation. 


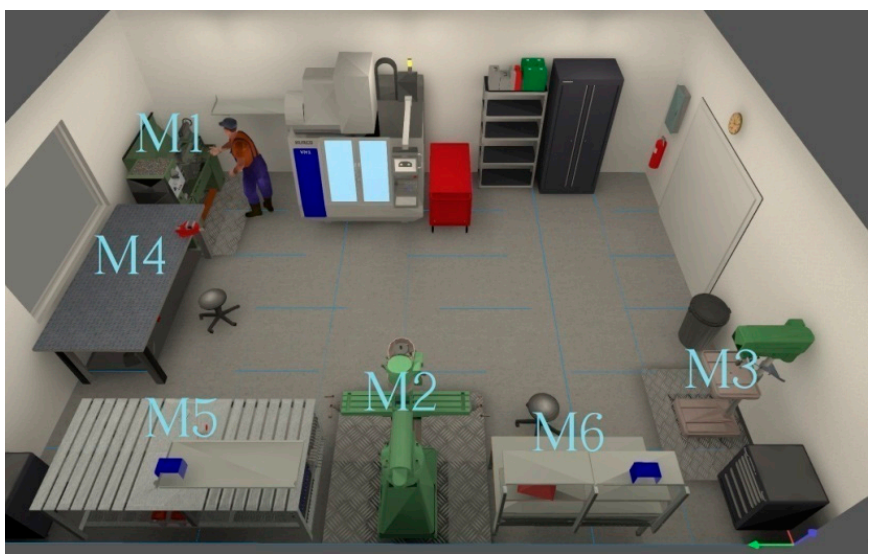

Figure 7. Computer model of a locksmith workshop with measuring points.

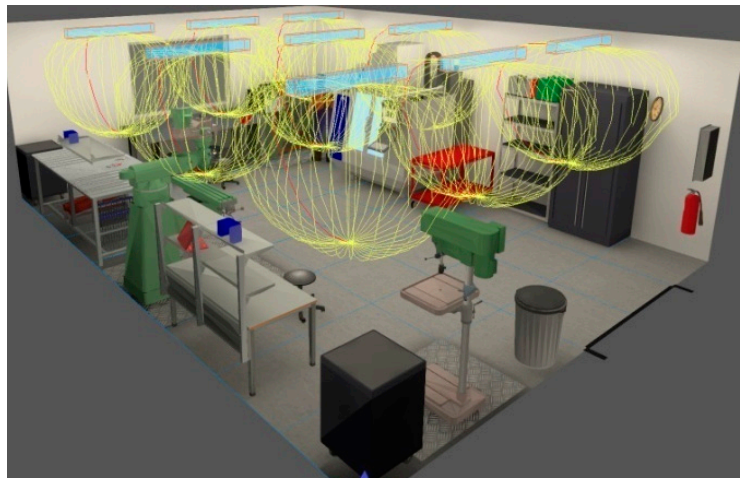

(a)

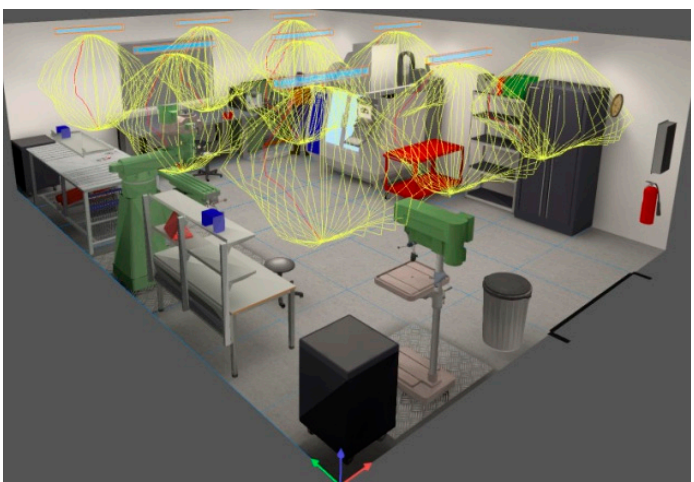

(b)

Figure 8. Simulation of the lighting in the: (a) original model (b) new model.

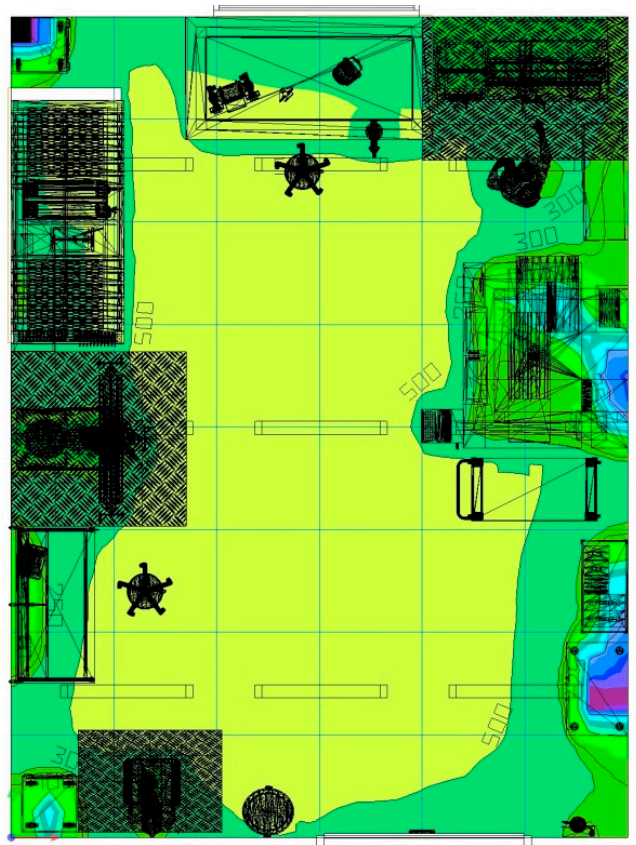

(a)

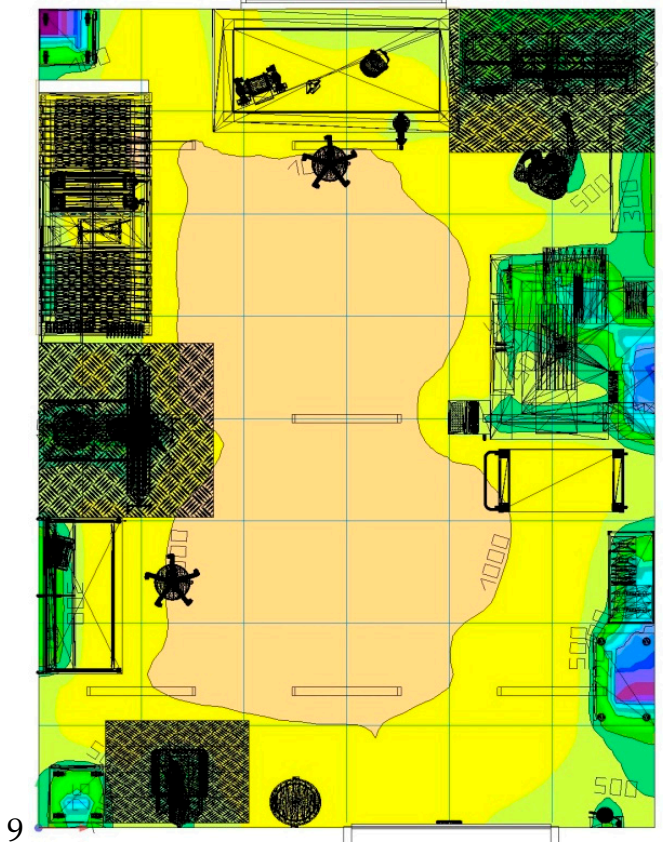

(b)

Figure 9. Illumination intensity values in the: (a) original model (b) new model. 
Table 13. DIALux results comparison; average light intensity and energy consumption.

\begin{tabular}{|c|c|c|c|c|c|c|c|c|c|c|}
\hline & M1 & M2 & M3 & $\begin{array}{c}\text { Em (lx) } \\
\text { M4 }\end{array}$ & M5 & M6 & Total & $\begin{array}{c}\text { Energy Consumption } \\
(\mathrm{kWh} / \mathrm{a})\end{array}$ & $\begin{array}{c}\text { LENI } \\
\left(\mathrm{kWh} / \mathrm{a} / \mathrm{m}^{2}\right)\end{array}$ & Costs (EUR/a) \\
\hline Original model & 365 & 542 & 495 & 467 & 483 & 371 & 450 & 1100-1500 & $23-31$ & $336-446$ \\
\hline New model & 626 & 858 & 832 & 804 & 840 & 657 & 787 & $890-1000$ & $19-21$ & $267-304$ \\
\hline
\end{tabular}

\section{Discussion}

The results of the study indicate that there is a moderate relationship between the health and well-being of employees and most of the examined factors related to the working conditions. The working environment is an integral part of humans because we spend about one third of our lives in it. The topic of the impact of the workplace environment on the employee has a place in many kinds of research and discussions of experts $[2,4,7,11,14]$. A suitable working environment should create a sense of safety and comfort and help improve the performance of employees and reduce accidents and human errors. The work environment is one of the significant factors in recruiting and retaining employees. Unsuitable and unpleasant working conditions can be a reason for an employee to leave work. Many people prefer a clean and comfortable working environment when choosing a job, sometimes even at the cost of a higher salary. The perception of the work environment is subjective; it depends on the individual's emotional state, character, aesthetic feelings, and needs. Therefore, the aim is to create such working conditions that the majority of employees will be satisfied. What the employer invests in improving the working environment will reflect in the efficiency of the employees' work.

One of the physical factors that affects the well-being of employees is lighting. Natural daylight has many health benefits for humans. It affects the biological clock, mood and helps the body produce vitamin D. However, it is often not possible to supply the body with enough daylight during the day, due to the amount of time we spend indoors, including the working environment. A combination of daylight and artificial lighting is often used in workplaces, but sometimes work is performed only under artificial lighting, for example, a night shift. Responses from our survey indicate that night shift workers were more prone to feelings of visual discomfort, headache, and SAD symptoms. Exposure of the body to artificial lighting at night disrupts the circadian rhythms $[3,5,16,29,30]$. Blue light plays an important role in this disturbance, as it is contained in natural daylight, but also in light-emitting diodes (lights, monitors, screens). The blue light has a stimulating effect, helping us to wake up and stay awake during the day, it suppresses the production of melatonin [24-27,32]. Continuous suppression of melatonin production can result in various health problems (e.g., eye irritation, insomnia, etc.) therefore, the night-time exposure to blue light should be minimized. Most modern LED devices and luminaires are designed so that they emit warmer colors with minimum blue spikes. Therefore, it is important to consider many factors when designing workplace lighting, especially for night shifts. Research to date has provided many important findings of the health risks of shift work and artificial lighting. However, shift work is still a necessity in many people's lives. Therefore, there is a need for further research on how to minimize these workplace hazards.

\section{Conclusions}

This article deals with the influence of several factors of the work environment such as age, length of employment, visual demand of the work, satisfaction with lighting, and the impact of shift work on the health and well-being of the employee. The main objective of this study was to highlight the importance of proper working environment conditions as well as lighting design for visual comfort, safety, and health of the employees.

The first part of the paper uses questionnaire survey and statistical methods to examine the dependence between six characters (employee's age, length of employment, visual demand of work task and satisfaction with lighting conditions, night shift and day shift) and occurrence of health-related problems (i.e., eye discomfort, headache, eye fatigue, and seasonal affective disorder symptoms). 
The results of the study indicate that factors such as the age of the employee, the visual demands of work task, satisfaction with lighting, and shift work are associated with an increased occurrence of health problems and discomfort. Given that the research results are based on the subjective opinions and feelings of the company employees, future research will focus on objectifying the influence of these factors on the employee's well-being in the workplace.

The second part of the study was focused on assessing the current state of lighting conditions in the chosen locksmith workshop by measuring selected lighting parameters and by creating a computer lighting model in lighting design software DIALux evo 9.2. The results of measurements and analysis of the light model indicate insufficient lighting. Therefore, a new variant of the workshop lighting model was proposed, in which the current luminaries were replaced by new, more efficient LED luminaries, to meet the requirements of legislation and improve lighting conditions as well as reduce energy consumption. When assessing the lighting, it is necessary to realize that its energy intensity is a secondary aspect in the development of lighting design. Requirements for lower energy consumption of lighting can in no case take precedence over requirements for lighting at work. A few guidelines on how to create a setting that increases satisfaction and productivity of employees:

- Take the biological aspect of lighting into account. Natural daylight synchronizes the circadian rhythm and it influences to sleep-wake cycle and this has a big influence on people's health and productivity.

- Make artificial lighting adaptable according to the daytime, season, performed activity, and to the individual needs of the user.

- Provide adequate lighting for people to carry out their visual tasks to create a sense of space and depth, give visual comfort, and add a pleasant atmosphere to the working environment.

In summary, working environment factors present widespread challenges to employees' health, safety, and well-being; therefore, there is a need for continuous evaluation and improvement of working conditions to keep employees efficient and productive.

Author Contributions: Conceptualization, R.K. and E.L.; methodology, R.K. and E.L.; software, L.D.; validation, E.L. and R.K.; formal analysis, A.Y. and L.D.; investigation, L.D. and A.Y.; resources, R.K.; data curation, L.D. and A.Y.; writing-original draft preparation, L.D. and R.K.; writing-review and editing, A.Y. and E.L.; visualization, L.D.; supervision, R.K. and E.L.; project administration, A.Y. and L.D.; funding acquisition, E.L. All authors have read and agreed to the published version of the manuscript.

Funding: This research was funded by the Cultural and Educational Grant Agency of the Ministry of Education, Science, Research, and Sport of the Slovak Republic under project KEGA No. 011TUKE4/2021 titled "Implementation of current scientific-research, technical and methodological solutions in the environmental engineering field into the educational process at universities".

Institutional Review Board Statement: Not applicable.

Informed Consent Statement: Informed consent was obtained from all subjects involved in the study.

Data Availability Statement: The data presented in this study are available on request from the corresponding author.

Conflicts of Interest: The authors declare no conflict of interest.

\section{References}

1. Boyce, P.R. Lighting research for interiors: The beginning of the end or the end of the beginning. Light. Res. Technol. 2004, 36, 283-293. [CrossRef]

2. Gligor, V. Luminous Environment and Productivity at Workplaces. Ph.D. Thesis, Helsinki University of Technology, Espoo, Finland, 2004.

3. Papatsimpa, C.; Linnartz, J.-P. Personalized Office Lighting for Circadian Health and Improved Sleep. Sensors 2020, 20, 4569. [CrossRef] 
4. Harrison, E.M.; Schmied, E.A.; Easterling, A.P.; Yablonsky, A.M.; Glickman, G.L. A Hybrid Effectiveness-Implementation Study of a Multi-Component Lighting Intervention for Hospital Shift Workers. Int. J. Environ. Res. Public Health 2020, 17, 9141. [CrossRef] [PubMed]

5. Finger, A.; Kramer, A. Mammalian circadian systems: Organization and modern life challenges. Acta Physiol. 2021, 231, 13548. [CrossRef]

6. Durak, A.; Olguntürk, N.C.; Yener, C.; Güvenç, D.; Gürçınar, Y. Impact of lighting arrangements and illuminances on different impressions of a room. Build. Environ. 2007, 42, 3476-3482. [CrossRef]

7. Hughes, P.C.; McNelis, J.F. Lighting, productivity, and the work environment. Lighting Des. Appl. 1978, 8, 32-38.

8. Veitch, J. Psychological Processes Influencing Lighting Quality. J. Illum. Eng. Soc. 2001, 30, 124-140. [CrossRef]

9. Leproult, R.; Colecchia, E.F.; L'Hermite-Balériaux, M.; Van Cauter, E. Transition from Dim to Bright Light in the Morning Induces an Immediate Elevation of Cortisol Levels. J. Clin. Endocrinol. Metab. 2001, 86, 151-157. [CrossRef] [PubMed]

10. Zhang, R.; Campanella, C.; Aristizabal, S.; Jamrozik, A.; Zhao, J.; Porter, P.; Ly, S.; Bauer, B.A. Impacts of Dynamic LED Lighting on the Well-Being and Experience of Office Occupants. Int. J. Environ. Res. Public Health 2020, 17, 7217. [CrossRef] [PubMed]

11. de Kort, Y.; Smolders, K. Effects of dynamic lighting on office workers: First results of a field study with monthly alternating settings. Light. Res. Technol. 2010, 42, 345-360. [CrossRef]

12. Fukumura, Y.E.; Gray, J.M.; Lucas, G.M.; Becerik-Gerber, B.; Roll, S.C. Worker Perspectives on Incorporating Artificial Intelligence into Office Workspaces: Implications for the Future of Office Work. Int. J. Environ. Res. Public Health 2021, 18, 1690. [CrossRef]

13. Moore, T.; Carter, D.; Slater, A. User attitudes toward occupant controlled office lighting. Light. Res. Technol. 2002, 34, 207-216. [CrossRef]

14. Andrejiová, M.; Piňosová, M.; Králiková, R.; Dolník, B.; Liptai, P.; Dolníková, E. Analysis of the Impact of Selected Physical Environmental Factors on the Health of Employees: Creating a Classification Model Using a Decision Tree. Int. J. Environ. Res. Public Health 2019, 16, 5080. [CrossRef] [PubMed]

15. Baloch, R.M.; Maesano, C.N.; Christoffersen, J.; Mandin, C.; Csobod, E.; de Oliveira Fernandes, E.; Annesi-Maesano, I.; On Behalf of the SINPHONIE Consortium. Daylight and School Performance in European Schoolchildren. Int. J. Environ. Res. Public Health 2021, 18, 258. [CrossRef] [PubMed]

16. Sunde, E.; Pedersen, T.; Mrdalj, J.; Thun, E.; Grønli, J.; Harris, A.; Bjorvatn, B.; Waage, S.; Skene, D.J.; Pallesen, S. Alerting and Circadian Effects of Short-Wavelength vs. Long-Wavelength Narrow-Bandwidth Light during a Simulated Night Shift. Clocks Sleep 2020, 2, 502-522. [CrossRef]

17. Juslén, H.; Tenner, A. Mechanisms involved in enhancing human performance by changing the lighting in the industrial workplace. Int. J. Ind. Ergon. 2005, 35, 843-855. [CrossRef]

18. Kralikova, R.; Wessely, E. Lighting Quality, Productivity and Human Health. In Proceedings of the 27th DAAAM International Symphosium on Intelligent Manufacturing and Automation, Mostar, Bosnia and Herzegovina, 26-29 October 2016; Volume 27, ISBN 1726-9679.

19. Markkanen, P. Knowledge Work in Campus Environment-Opportunities of New Technologies in Working and Learning Spaces. In Proceedings of the 6th Annual Symposium of Architectural Research 2014 and The Annual NAAR Symposium, Oulu, Finland, 23-25 October 2014.

20. Frumkin, H. Healthy places: Exploring the evidence. Am. J. Public Health 2003, 93, 1451-1456. [CrossRef] [PubMed]

21. Peña-García, A.; Salata, F. Indoor Lighting Customization Based on Effective Reflectance Coefficients: A Methodology to Optimize Visual Performance and Decrease Consumption in Educative Workplaces. Sustainability 2021, 13, 119. [CrossRef]

22. Lee, H.; Zhao, X.; Seo, J. A Study of Optimal Specifications for Light Shelves with Photovoltaic Modules to Improve Indoor Comfort and Save Building Energy. Int. J. Environ. Res. Public Health 2021, 18, 2574. [CrossRef] [PubMed]

23. Setyantho, G.R.; Park, H.; Chang, S. Multi-Criteria Performance Assessment for Semi-Transparent Photovoltaic Windows in Different Climate Contexts. Sustainability 2021, 13, 2198. [CrossRef]

24. Rohan, K.J.; Mahon, J.N.; Evans, M.; Ho, S.Y.; Meyerhoff, J.; Postolache, T.T.; Vacek, P.M. Randomized Trial of CognitiveBehavioral Therapy Versus Light Therapy for Seasonal Affective Disorder: Acute Outcomes. Am. J. Psychiatry 2015, 172, 862-869. [CrossRef] [PubMed]

25. Nussbaumer-Streit, B.; Forneris, C.A.; Morgan, L.C.; Van Noord, M.G.; Gaynes, B.N.; Greenblatt, A.; Wipplinger, J.; Lux, L.J.; Winkler, D.; Gartlehner, G. Light therapy for preventing seasonal affective disorder. Cochrane Database Syst. Rev. 2019, 3, CD011269. [CrossRef] [PubMed]

26. Meesters, Y.; Winthorst, W.H.; Duijzer, W.B.; Hommes, V. The effects of low-intensity narrow-band blue-light treatment compared to bright white-light treatment in sub-syndromal seasonal affective disorder. BMC Psychiatry 2016, 16, 27. [CrossRef] [PubMed]

27. Campbell, P.D.; Miller, A.M.; Woesner, M.E. Bright Light Therapy: Seasonal Affective Disorder and Beyond. Einstein J. Biol. Med. 2017, 32, E13-E25.

28. Lee, E.E.; Amritwar, A.; Hong, L.E.; Mohyuddin, I.; Brown, T.; Postolache, T.T. Daily and Seasonal Variation in Light Exposure among the Old Order Amish. Int. J. Environ. Res. Public Health 2020, 17, 4460. [CrossRef] [PubMed]

29. Bellia, L.; Fragliasso, F. Good Places to Live and Sleep Well: A Literature Review about the Role of Architecture in Determining Non-Visual Effects of Light. Int. J. Environ. Res. Public Health 2021, 18, 1002. [CrossRef] [PubMed]

30. Juda, M.; Liu-Ambrose, T.; Feldman, F.; Suvagau, C.; Mistlberger, R.E. Light in the Senior Home: Effects of Dynamic and Individual Light Exposure on Sleep, Cognition, and Well-Being. Clocks Sleep 2020, 2, 557-576. [CrossRef] [PubMed]

31. Schlangen, L.; Price, L. The Lighting Environment, Its Metrology, and Non-visual Responses. Front. Neurol. $2021,12,624861$. [CrossRef] [PubMed] 
32. Figueiro, M.G.; Nagare, R.; Price, L. Non-visual effects of light: How to use light to promote circadian entrainment and elicit alertness. Light. Res. Technol. 2018, 50, 38-62. [CrossRef] [PubMed]

33. Price, L.; Udovičić, L.; Behrens, T.; van Drongelen, A.; Garde, A.H.; Hogenelst, K.; Jensen, M.A.; Khazova, M.; Nowak, K.; Rabstein, S.; et al. Linking the non-visual effects of light exposure with occupational health. Int. J. Epidemiol. 2019, 48, 1393-1397. [CrossRef]

34. Decree, No. 206/2011 Coll and Decree No. 541/2007 Coll on Details of Lighting Requirements at Work. Ministry of Health of the Slovak Republic. Available online: https:/ / www.slov-lex.sk/pravne-predpisy (accessed on 2 February 2021).

35. Dialux is the Software for Your Professional Lighting Design. Available online: https://www.dialux.com/en-GB/dialux (accessed on 8 February 2021). 